\title{
KESULITAN BELAJAR MATERI MATEMATIKA TERHADAP SISWA DI SEKOLAH DASAR(SD)
}

\author{
Sakinah Aprianni ${ }^{1}$; Sepnita Nurma Wardhani ${ }^{2}$; Syafna Mardhatillah ${ }^{3}$; Manisha Azzuhro ${ }^{4}$; Rora \\ RizkyWandini ${ }^{5}$; \\ ${ }^{12345}$ Program Studi Pendidikan Guru Madrasah Ibtidaiyah, Universitas Islam Negeri \\ Sumatera Utara, Jl. WilliemIskandar Ps V Medan Estate Kec. PercutSei Tuan Kab. Deli \\ Serdang Sumatera Utara \\ sakinahaprianni@gmail.com ${ }^{1}$; sepnita022@gmail.com ${ }^{2}$; syafnamardhatillah12@gmail.com ${ }^{3}$; \\ manishaazzuhro@gmail.com ${ }^{4}$; rorarizkiwandini@uinsu.ac.id ;
}

\begin{abstract}
Abstrak
Riset ini bertujuan untuk mengenali seberapa kesusahan belajar yang di natural tiap anak berbeda, serta postingan ini diberikan kemudahan buat memahami bermacam berbagai kesusahan belajar serta solusinya. Jumlah priset dalam riset ini sebanyak 4 orang. Riset ini dicoba buat menganalisis serta mengenali faktor-faktor pemicu kesusahan siswa (Sekolah Dasar). Tulisan ini bertujuan membahas kesulitan belajar materimatematika terhadap siswa di sekolah dasar(SD). Kajian ini menggunakan metode studi kepustakaan dengan mengumpulkan data dari berbagai sumber seperti buku dan artikel ilmiah mengenai pembahasan terkait. Kemudian melakukan analisis deskriptif data yang dipaparkan secara detil.Adapunhasilpenelitianinibahwakesusahan belajar merupakan hambatan ataupun kendala yang dinatural oleh anak ataupun juga anak muda yang diakibatkan terdapatnya ketidak seimbangan antara ilmu pengetahuan dengan keahlian yang dipunyai oleh anak ataupun juga anak muda yang sepatutnya dicapai. Hambatan yang dirasakan oleh anak mungkin besar diakibatkan oleh terdapatnya kendala sistem syaraf otak pada anak sehingga dapat menimbulkan kesusahan belajar kepada anak.
\end{abstract}

Kata kunci : Kesulitan belajarmatematika, Sekolah Dasar.

\begin{abstract}
Abtract
This research aims to identify how different learning difficulties are experienced by each child, and this post makes it easy to understand the various learning difficulties and their solutions. The number of researchers in this study was 4 people. This research was attempted to analyze and identify the factors that trigger student distress (Elementary School). This paper aims to discuss the difficulties in learning mathematics material for students in elementary schools (SD). This study uses a literature study method by collecting data from various sources such as books and scientific articles on related discussions. Then perform a descriptive analysis of the data presented in detail. The results of this study indicate that learning difficulties are obstacles or obstacles experienced by children or young people due to an imbalance between knowledge and skills possessed by children or young people that should be achieved. The obstacles felt by children may be caused by the presence of obstacles in the brain's nervous system in children so that it can cause learning difficulties for children.
\end{abstract}

Keywords: Difficulty learning mathematics, Elementary School 


\section{PENDAHULUAN}

Selama ini pembelajaraan Matematika (MTK) di jenjang pendidikan dasar, terutama Sekolah Dasar (SD) atau Madrasah Ibtidaiyah (MI) masih ekstrim. Sebab, Matematika dari dulu seolah-olah memang "menegangkan", maka wajar jika anak-anak SD dari dulu sampai sekarang tidak menemukan kenyamanan belajar $100 \%$ (Kastarina, dkk. 2016:269-281).

Wajar saja masih banyak anak-anak SD terhantui saat pembelajaran Matematika yang berdampak pada rendahnya hasil belajar mereka. Rendahnya prestasi belajar siswa pada mata pelajaran Matematika sering dianggap hal yang wajar sehingga banyak guru dan orang tua tidak bersungguh-sungguh ber-upaya untuk menyelesaikan masalahnya (Sugiman, 2009). Di sisi lain penguasaan konsep Matematika yang sangat dibutuhkan dalam kehidupan sehari-hari, sehingga anak dan orang tua merasa bahwa kebutuhan bersosialisasi di sekitar lingkungannya terhambat. Padahal menurut yang tersirat pada Kurikulum Tingkat Satuan Pendidikan (KTSP) sebenarnya ilmu yang diajarkan di sekolah adalah dalam rangka menyiapkan anak didik untuk dapat hidup di tengah-tengah masyarakat lingkungannya (Sudirjo, dkk, 2009). Begitu juga Kurikulum 2013 yang mengamanatkan pembelajaran berbasis Saintific yang itu sangat Integral, antara satu mata pelajaran dengan yang lainnya. Maka dari itu, adanya penerapan kurikulum yang gantiganti harus menjadi pertimbangan guru SD dalam menentukan pembelajaran Matematika dan Mapel lainnya yang berkualitas serta menyenangkan (Setiawan, 2020).

Untuk menyesuaikan kebutuhan penguasaan konsep ilmu bagi anak dalam menghadapi tantangan di tengah-tengah masyarakat lingkungannya perlu di temukan caracara yang dapat menanamkan konsep ilmu di sekolah pada diri mereka. Maka pada penelitian ini peneliti berusaha menemukan cara yang efektif untuk menanamkan konsep ilmu di sekolah agar dapat di terapkan anak dalam kehidupan sehari-harinya, yaitu dengan menggunakan berbagai strategi, model, dan juga media pembelajaran Matematika yang menyenangkan. Sebab, tanpa adanya rasa nyaman bagi anak SD saat belajar Matematika, maka akan sulit membuat mereka paham dengan materi Matematika.

\section{METODE}

Tulisan ini bertujuan membahas kesulitan belajar materimatematika terhadap siswa di sekolah dasar(SD).Kajian ini menggunakan metode studi kepustakaan dengan 
mengumpulkan data dari berbagai sumber seperti buku dan artikel ilmiah mengenai pembahasan terkait. Kemudian melakukan analisis deskriptif data yang dipaparkan secara detil.

\section{HASIL DAN PEMBAHASAN}

Pembelajaran matematika di SD selama ini memang masih dipahami sebagai pembelajaran yang "susah" bagi guru. Bahkan, anak-anak SD sendiri dan juga orang tua wali juga sama, bahwa matematika itu susah, membosankan dan menenggangkan (Hidayati, 2017). Padahal, kunci utamanya itu diguru dalam pembelajaran yang bisa menggunakan dan menerapkan berbagai model, pendekatan, strategi, metode, media pembelajaran matematika yang menyenangkan dan mengubah "stikma negatif" pada matematika pelajaran di SD. Dalam konteks pembelajaran, penggunaan strategi, model, pendekatan, media akan membuat mereka masuk kedalam situasi yang menyenangkan sehingga pembelajaran Matematika yang biasanya terasa tegang dan membosankan dapat diubah menjadi situasi yang menyenangkan dan dapat menguasai konsep ilmu yang di tanamkan dengan mudah (Sugiman, 2009).

Di sisi lain pula bahwa Kurikulum Tingkat Satuan Pendidikan (KTSP) menyiratkan tujuan setiap pembelajaran tidak hanya untuk menghasilkan peningkatan aspek kognitif saja tetapi tidak aspek-aspek yang lain seperti afektif dan psikomotor. Sementara kurikulum 2013 juga sama, tidak hanya ber orientasi pada aspek kognitif saja, namun juga aspek afektif dan juga psikomotorik (Rizqis, dkk, 2019).

Dalam penggunaan pendekatan pembelajaran Matematika, harus menggunakan prinsip yang dapat mengembangkan ketiga aspek tersebut. Pasalnya, karakter pembelajaran Matematika di SD secara umum, disamping anak akan berkompetisi dalam menghitung (kognitif) siswa akan berkomunikasi dan berkompetisi sehat dengan teman-temannya (afektif), serta dapat melaksakan tugas-tugasnya seperti menjual, dan membeli (psikomotor) (Hidayati, 2009).

Proses pembelajaran yang berkualitas tidak hanya dapat dilihat dari hasil anak saja, tetapi juga tidak kalah penting dilihat dari motivasi siswa dalam proses pembelajaran. Maka meningkatan motivasi siswa dalam proses pembelajaran. Maka akan meningkatkan motivasi siswa dalam proses pembelajaran yang diharapkan dapat meningkatkan hasil belajar yang mencangkup aspek kognitif, afektif dan psikomotor (Manzilatussifa, 2007). 
Dalam pembelaajaran Matematika, bagaimanakah caranya agar siswa tidak melupakan materi pelajaran yang telah di terimanya agar siswa nantinya siap menghadapi tes kenaikan kelas yang siap atau tidak siap harus mereka hadapi? Bagaimanakah membuat suatu materi ajar agar tidak terlupakan oleh anak didik? Dalam hal ini guru harus mencari metode harus mecari metode untuk mengingatkan segala memori dibenak siswa yang telah mereka terima. Guru harus bisa membangkitkan kembali memori itu (Manzilatussifa, 2007). Salah satu metode pengajaran yang bisa membuat anak bisa dan harus mengingat kembali materi pelajaran yang telah mereka terima adalah cara belajar aktif model pembelajaran meninjau ulang kesulitan pada materi pelajaran. Belajar memerlukan keterlibatan mental dan kerja siswa sendiri. Penjelasan dan pemeragaan semata tidak akan membuahkan hasil belajar yang hanyalah kegiatan belajar aktif (Manzilatussifa, 2007).

Agar belajar menjadi aktif, siswa harus mengerjakan banyak sekali tugas. Mereka harus menggukan otak, mengkaji gagasan, memecahkan masalah, dan menerapkan apa yang mereka pelajari. Belajar aktif harus gesit, menyenagkan, bersemangat, dan penuh gairah. Siswa bahkan sering meninggalkan tempat duduk mereka, bergerak leluasa dan berfikir keras (moving about dan thingking aloud) (Simbolon, 2014).

Dalam pembelajaran Matematika di SD tentu banyak faktor yang mempengaruhi hasil belajar anak-anak. Sebab keberhasilan sangat di pengaruhi oleh beberapa faktor. Faktorfaktor tersebut dapat dikelompokkan menjadi dua, yaitu Faktor dalam diri siswa itu sendiri (Ingtern) dan faktor dari luar diri siswa (ekstern) (Soejadi, 1988).

Pertama, intern. Faktor dalam diri siswa yang berpengaruh terhadap hasil belajar siswa diantaranya adalah kecakapan, minat, bakat, usaha, motivasi, perhatian, kelemahan, dan kesehatan, serta kebiasaan siswa. Minat belajar berkaitan seberapa besar individu merasa suka atau tidak suka terhadap suatu materi yang dipelajari siswa. Minat inilah yang harus dimunculkan lebih awal dalam diri siswa. Minat, motivasi, dan perhatian siswa dapat dikondisikan oleh guru karena setiap individu memiliki kecakapan yang berbeda-beda (Indrawijaya, 2018).

Kedua, ekstern. Faktor dari luar diri siswa yang mempengaruhi hasil belajar diantaranya adalah lingkungan fisik dan non fisik (termasuk suasana kelas dalam belajar seperti riang gembira, menyenangkan). Guru merupakan faktor yang paling berpengaruh terhadap proses maupun hasil belajar. Untuk memahami faktor intern yang mempengaruhi 
belajar siswa guru dapat melakukan beberapa pendekatan, diantaranya dengan wawancara, observasi, kunjungan rumah, dokumentasi atau isian berupa angket (kuesioner) (Iskandar, 2019).

Untuk menilai kemampuan siswa harus dilakukan authentic assesmen atau penilaian sebenarnya, yang dimaksud untuk menilai keseluruhan aspek, yaitu kognitif, afektif, psikomonorik. Berikut ini beberapa penilaian yang harus dilakukan :

1. Tes Tulis

Tes yang diberikan kepada pihak Teeste (pihak yang mengerjakan tes) yang harus di jawab secara tertulis. Bentuk tes ini berupa aitem isian, aitem tes uraian benar salah dan pilihan ganda.

2. Tes Lisan

Yaitu bentuk tes formal yang dilakukan secara lisan atau tidak tertulis baik perintah maupun jawabanya secara lisan. Tes lisan dilaksanakan secara tatap muka langsung antara tester dengan seorang tester atau beberapa orang tester keunggulan tes ini yaitu tester bisa mengetahui tingkat kognitif anak secara ontentif. Kelemahannya tes ini semacam bisa bias dan kurang objektif bila tidak direncakan dengan baik.

3. Tes Kinerja

Sama dengan halnya tes tulis, tes kinerja juga berbentuk, seperti papernpenciltest, tes identifikasi, tes simulasi, dan tes uji peti kerja.

4. Tingkat kognitif peserta didik

Pada dasarnya tingkat kognitif tidak sama. Menurut piyaget perkembangan kognitif (mental) anak melalui 4 tahap yaitu: a. Sensorimotor (2Th), b. Preoperational (2-7Th) : c. Concrete operational (7-11 Th): Dan d. Formal operation (11 Hingga dewasa). Tentu saja tingkat kesulitan soal yang akan dibuat harus mempertimbangkan tahap-tahap perkembangan.

5. Metode observasi

Metode observasi dilakukan untuk mengumpulkan data tentang aktiiftas sesuai baik selama di dalam maupun diluar kelas. Melalui observasi akan dapat dikethaui tentang keadaan siswa apakah mereka telah menguasai suatu aspek atau kompetensi yang telah dipelajari selama proses pembelajaran atau belum. Misalnya selama berproses diskusi apakah para siswa telah berpartisipasi penuh, beragumen secara 
rasional. Menanggapi dengan baik, dan maupun menyimpulkan tentang apa yang dipelajari. Dilihat dari teknik pelaksaanya, observasi dapat dibedakan menjadi observasi terbuka, terfokus, terstruktur, Dan sistematis.

\section{PENUTUP}

Pembelajaran matematika sebenarnya tidak sulit tergantung dengan guru karena kunci utamanya itu ada diguru dalam pembelajaran yang bisa menggunakan dan menerapkan berbagai model, pendekatan, strategi, metode, media pembelajaran matematika yang menyenangkan dan mengubah "stikma negatif" pada matematika pelajaran di SD. Dalam konteks pembelajaran, penggunaan strategi, model, pendekatan, media akan membuat mereka masuk kedalam situasi yang menyenangkan sehingga pembelajaran Matematika yang biasanya terasa tegang dan membosankan dapat diubah menjadi situasi yang menyenangkan dan dapat menguasai konsep ilmu yang di tanamkan dengan mudah. Proses pembelajaran yang berkualitas tidak hanya dapat dilihat dari hasil anak saja, tetapi juga tidak kalah penting dilihat dari motivasi siswa dalam proses pembelajaran. Maka meningkatan motivasi siswa dalam proses pembelajaran. Maka akan meningkatkan motivasi siswa dalam proses pembelajaran yang diharapkan dapat meningkatkan hasil belajar yang mencangkup aspek kognitif, afektif dan psikomotor.

\section{DAFTAR PUSTAKA :}

Haryono, Didi. Filsafat Matematika "Suatu Tinjauan Epistemologis Dan Filosofis". Bandung: Alfabeta, 2015.

Hidayati, Arini Ulfah. "Melatih Keterampilan Berpikir Tingkat Tinggi Dalam Pembelajaran Matematika Pada Siswa Sekolah Dasar." Jurnal Pendidikan Dan Pembelajaran Dasar 4, no. 20 (2017): 143-56.

Indrawijaya. "Hubungan Disiplin Belajar Dan Minat Belajar Dengan Hasil Belajar Pkn Pada Materi Kebebasan Mengemukakan Pendapat Siswa Kelas Vii Di Smps Cinta Nusa Sentul Kabupaten Bogor." MODELING: Jurnal Program Studi PGMI 5, no. September (2018): 206-15.

Iskandar, Wahyu. "Kemampuan Guru Dalam Berkomunikasi Terhadap Peningkatkan Minat Belajar Siswa Di SDIT Ummi Darussalam Bandar Setia." AR-RIAYAH : Jurnal Pendidikan Dasar 3, no. 2 (2019): 135. https://doi.org/10.29240/jpd.v3i2.1126.

Kastarina, Yuni, Tegus S Karniman, and Anggraini. "Penerapan Model Pembelajaan Kooperatif Tipe Team Assisted Individualization Untuk Meningkatkan Hasil Belajar Siswa Pada Fungsi Komposisi Di Kelas XI IPA I SMAN 7 Palu." AKSIOMA Jurnal Pendidikan Matematika 5, no. 3 (2016): 269-81.

Lely Halimah, R. Deti Rostika, Encep Sudirjo. "Pengembangan Model Penyusunan Kurikulum Tingkat Satuan Pendidikan ( Ktsp ) Ridwan Bait S." Jurnal Penelitian 10, 
no. 2 (2009).

Manzilatusifa, Uus. "Pemberian Motivasi Guru Dalam Pembelajaran." Educare 5, no. 1 (2007): 67-73. http://jurnal.fkip.unla.ac.id/index.php/educare/article/view/59.

Rizqia, Maulida, Wahyu Iskandar, Nurzakiah Simangunsong, and Suyadi Suyadi. "Analisis Psikomotorik Halus Siswa Ditinjau Dari Keterampilan Menggambar Anak Usia Dasar SD." Al-Aulad: Journal of Islamic Primary Education 2, no. 2 (2019): 45-53. https://doi.org/10.15575/al-aulad.v2i2.5212.

Setiawan, Adib Rifqi. "Desain Pembelajaran Untuk Membimbing Siswa Sekolah Dasar Dalam Memperoleh Literasi Saintifik," no. April 2020 (2020). https://doi.org/10.35542/osf.io/u59f8.

Simbolon, Naeklan. "Faktor Faktor Yang Mempengaruhi Minat Belajar Peserta Didik." Elementary School Journal Pgsd Fip Unimed 1, no. 2 (2014): 14-19.

Soejadi, R. Kiat Pendidikan Matematika Di Indonesia: Konstatasi Keadaan Masa Kini Menuju Harapan Masa Depan. Jakarta: Departemen Pendidikan Nasional, 1988.

Sugiman. "Pandangan Matematika Sebagai Aktivitas Insani Beserta Dampak Pembelajarannya." Yogyakarta: Prosiding of SemNas Matematika dan Pendidikan Matematika,FMIPA UNY, 2009. 